\title{
The 6K2 Protein and the VPg of Potato Virus A Are Determinants of Systemic Infection in Nicandra physaloides
}

\author{
Minna-Liisa Rajamäki and Jari P. T. Valkonen \\ Department of Plant Biology, Genetic Centre, SLU, PO Box 7080, S-750 07 Uppsala, Sweden; and Institute \\ of Biotechnology, Viikki Biocenter, PO Box 56, FIN-00014 University of Helsinki, Finland \\ Accepted 1 September 1999.
}

\begin{abstract}
Infection with the isolate PVA-M of potato virus A (PVA; genus Potyvirus) is restricted to the inoculated leaves of Nicandra physaloides (Solanaceae), whereas the isolate PVA-B11 infects plants systemically by 10 days post inoculation. Resistance to systemic infection was shown to develop during plant growth. A recombinant virus (B11$M)$ in which a 1,208-nucleotide sequence of the full-length cDNA clone of PVA-B11 was replaced with the corresponding sequence from PVA-M displayed a phenotype similar to that of PVA-M. The replaced sequence contained four amino acid differences between the two isolates: one in the $6 \mathrm{~K} 2$ protein and three in the viral genome-linked protein ( $\mathrm{VPg})$. Site-directed mutagenesis of the cDNA clones and inoculation of the mutants to $N$. physaloides indicated that the amino acid substitutions of Met5Val in the $6 \mathrm{~K} 2$ protein or Leu185Ser in the VPg permitted vascular movement and systemic infection. However, resistance was only partially overcome by these changes, since systemic infection proceeded at a slower rate than with PVA-B11. The amino acid substitution Val116Met in the VPg alone was sufficient to overcome resistance and recover the phenotype of the isolate PVAB11. These data indicated that both the $6 \mathrm{~K} 2$ protein and the VPg were avirulence determinants of PVA-M in $N$. physaloides and suggested a possibly coordinated function of them in the vascular movement of PVA.
\end{abstract}

Viruses utilize the active intra- and intercellular transport mechanisms for movement from the initially infected cell to vascular tissue and are transported to different parts of the plant via the phloem following the source-sink partitioning of photoassimilates (Leisner et al. 1993; Ding 1998; Santa Cruz 1999). Cell-to-cell trafficking of macromolecules is regulated and the transport of viral RNA requires assistance from the viral movement proteins (MPs) (Imlau et al. 1999; Oparka et al. 1999). Therefore, compatible virus-host interactions are crucial for reaching the phloem and loading the virus to the

Corresponding author: Jari Valkonen; Department of Plant Biology, Genetic Centre, SLU, PO Box 7080, S-750 07 Uppsala, Sweden; E-mail: jari.valkonen@vbiol.slu.se

Nucleotide and/or amino acid sequence data can be found at the EMBL data base as accession no. AJ132007. vascular transport system, followed by systemic infection. Mutations resulting in less efficient or incompatible interactions between the MP and putative host factors reduce cell-tocell movement and may prevent systemic infection (Wang et al. 1998). The block of virus movement is often found at the bundle sheath-phloem interface (Santa Cruz 1999). Alternatively, an induced response triggered by virus infection may restrict cell-to-cell movement, phloem-dependent or systemic movement, or both, and block systemic infection (Culver 1997; Weber and Pfitzner 1998).

The virus species in the genus Potyvirus have no dedicated MPs but many viral proteins are involved in virus movement (Carrington et al. 1998). The single-stranded messengerpolarity genome encodes a single polyprotein that is autoproteolytically processed to produce up to 10 proteins (Riechmann et al. 1992), several of which are involved in virus movement. These include the helper component-proteinase (HC-Pro) (Cronin et al. 1995), cylindrical inclusion (CI) protein (Carrington et al. 1998), coat protein (CP) (Dolja et al. 1994), and viral genome-linked protein (VPg) (Schaad et al. 1997b; Nicolas et al. 1997).

Recent studies have identified the VPg as the avirulence determinant for several virus-host combinations in which the potyvirus fails to infect the resistant host systemically and cause a disease. Tobacco plants (Nicotiana tabacum L.) carrying the recessive resistance gene $v a$ are not systemically infected with tobacco vein mottling virus (TVMV), but substitutions in four closely situated amino acid residues in the central part of the VPg allow the isolate TVMV-S to overcome the resistance (Nicolas et al. 1997). Spontaneous amino acid substitutions in almost the same region of the VPg are found in isolates of potato virus $\mathrm{Y}$ (PVY) that overcome the $v a$-mediated resistance (Masuta et al. 1999). In tobacco etch virus (TEV), amino acid substitutions within another, more $\mathrm{N}$ proximal region of the VPg permit systemic infection in the resistant tobacco cv. V20 (Schaad et al. 1997b). Certain pathotypes of pea seed-borne mosaic virus (PSbMV) cannot detectably infect leaves of pea plants carrying the recessive resistance gene $s b m-1$, but resistance is overcome following amino acid substitutions in the VPg (Keller et al. 1998). For each of the virus-host combinations above, no induced resistance response of the host was reported.

The VPg is processed from the N-terminal part of the NIa protein, separated from the proteinase domain (NIa-Pro) by a 
suboptimal cleavage site (Shahabuddin et al. 1988, Schaad et al. 1996). The sequence encoding a small 6-kDa protein (6K2) is positioned immediately upstream of the NIa domain. The $6 \mathrm{~K} 2$ protein is found as a polyprotein with the VPg and the NIa protein in infected plants (Restrepo-Hartwig and Carrington 1994). The VPg is covalently attached to the $5^{\prime}$ terminus of viral RNA via a conserved tyrosine residue (Murphy et al. 1991), which is required for virus replication (Schaad et al. 1996). Many studies suggest that the VPg is incorporated in the viral replication complex that includes several plant and viral proteins (Schaad et al. 1996; Fellers et al. 1998; Lai 1998). The VPg is, hence, a multifunctional protein involved in virus movement and replication. The $6 \mathrm{~K} 2$ protein possesses membrane-binding activity and is needed for genome amplification (Restrepo-Hartwig and Carrington 1994; Schaad et al. 1997a).

Potato virus A (PVA; Bartels 1971; Puurand et al. 1994) is a member of the family Potyviridae containing the largest number of recognized plant virus species (Riechmann et al. 1992; Shukla et al. 1994; Faquet and Mayo 1999). Several PVA isolates have been studied and found to differ genetically and in biological traits (Valkonen et al. 1995; Rajamäki et al. 1998). Most of the biological differences have not been mapped to any particular region of the PVA genome, except for differences in aphid transmissibility and virus accumulation in tobacco plants, both of which are associated with the same Nterminal motif of the coat protein (Andrejeva et al. 1999). Many PVA isolates induce a severe vein chlorosis and mosaic disease in Nicandra physaloides L. (family Solanaceae), except for the isolate PVA-M, which does not infect this species systemically and causes no disease. Thus, PVA-M is avirulent (Shaner et al. 1992) in this host, and the work reported here was done to map the avirulence determinants in PVA-M. The term "avirulence determinant" is used instead of "avirulence factor" to reflect the fact that the genetic basis of resistance to PVA-M is unknown in N. physaloides. "Avirulence factor" is usually used in the context of the gene-for-gene theory to denote the pathogen product that is recognized by a matching host receptor to induce defense responses (De Wit 1997). The results indicate that the $6 \mathrm{~K} 2$ protein and the VPg are both avirulence determinants of PVA-M in N. physaloides. The data also suggest a role for both proteins in the vascular movement of PVA.

\section{RESULTS}

\section{Resistance to PVA-M in N. physaloides var. Black Pod.}

Plants of $N$. physaloides var. Black Pod were sap inoculated with the PVA isolates M (PVA-M) and B11 (PVA-B11). The eight plants inoculated with PVA-M in two experiments developed no symptoms and contained no PVA antigen (CP) detectable by enzyme-linked immunosorbent assay (ELISA) in the upper, noninoculated leaves at 18 days post inoculation (dpi) (amounts of CP exceeding $12.8 \mathrm{ng}$ per $\mathrm{g}$ of leaf could be quantified, and approximately 10 -fold lower amounts detected but not quantified, by the ELISA used). In contrast, all eight plants inoculated with PVA-B11 developed vein chlorosis symptoms in the upper leaves at $10 \mathrm{dpi}$, which coincided with accumulation of PVA as detected by ELISA and reverse transcription-polymerase chain reaction (RT-PCR). High virus titers (>2,000 ng/g) and symptoms continued to develop in the young, upper leaves until 18 dpi. Inoculated leaves were infected with both isolates, as determined by ELISA at 10 or 14 dpi. The virus-inoculated and mock-inoculated leaves were damaged by mechanical (sap) inoculation, resulting in wilted areas. Quantification of virus was therefore considered inconclusive in the sap-inoculated leaves.

All plants of $N$. physaloides var. Black Pod grown from the seeds responded uniformly to infection. Therefore, progeny segregating for different systemic infection phenotypes could not be produced and genetic studies on resistance were not carried out.

\section{Avirulence determinants of PVA-M in N. physaloides map to the genomic region encoding the $6 \mathrm{~K} 2$ protein and the VPg.}

Comparison of the VPg-encoding sequences in PVA isolates (Kekarainen et al 1999; M.-L. Rajamäki, T. Kekarainen, I. Oruetxebarria, and J. P. T. Valkonen, unpublished data) revealed a number of predicted amino acid differences between the VPg of PVA-M and that of PVA-B11. A study published by other authors at the same time indicated that mutations in the VPg of TVMV overcome the $v a$ gene-mediated resistance expressed as restricted virus movement in tobacco plants (Nicolas et al. 1997). For these reasons, we decided to examine whether the VPg of PVA-M is an avirulence determinant in $N$. physaloides. A 1,208-nucleotide region from the genomic RNA of PVA-M flanked by unique SwaI and ApaI restriction sites (Fig. 1), encoding the C-terminal portion of the CI domain, the entire 6K2 and VPg domains, and a small portion of the $\mathrm{N}$ terminus of the NIa-Pro domain, was RTPCR cloned and sequenced. Comparison to the corresponding re-sequenced region from the infectious cDNA clone of PVAB11 revealed only 21 nucleotide changes and four predicted amino acid substitutions, one amino acid substitution (Val5Met) in the $6 \mathrm{~K} 2$ protein and three amino acid changes (Met116Val, His118Tyr, and Ser185Leu) in the VPg (Fig. 1). The positions of two amino acid substitutions in the VPg (amino acids 116 and 118) corresponded to the amino acid positions in the VPg of TVMV that permitted TVMV-S to overcome the $v a$ gene-mediated resistance in tobacco (Nicolas et al. 1997).

The SwaI-ApaI fragment of PVA-B11 cDNA was replaced with the corresponding fragment from PVA-M (construct B11M; Fig. 1). Plants of $N$. physaloides were inoculated by particle bombardment. No plant was systemically infected with B11-M at 18 dpi in the initial experiments, whereas all plants inoculated with PVA-B11 were systemically infected at $10 \mathrm{dpi}$. Inoculated leaves were infected with both viruses according to ELISA. These data suggested that the avirulence determinant of PVAM was located within the $S w a \mathrm{I}-A p a \mathrm{I}$ region.

However, plants inoculated at a very young developmental stage became systemically infected with B11-M (Fig. 2), which made it necessary to determine the growth stage for inoculation that would allow distinguishing the phenotypic differences between B11-M and PVA-B11 most clearly. Inoculations were carried out on plants at three different developmental stages (Fig. 2). At growth stage I, all plants inoculated with PVA-B11, most plants inoculated with B11-M, and also one plant inoculated with PVA-M were systemically infected. However, the virus titers were lower and the vein chlorosis symptoms were less severe in the leaves systemi- 
cally infected with PVA-M and B11-M than with PVA-B11. Symptoms continued to develop in the young top leaves as observed until $21 \mathrm{dpi}$. At the two older growth stages, II and III, few or no plants were systemically infected with PVA-M and B11-M, whereas the plants remained susceptible to PVAB11 (Fig. 2, Table 1). The greater number of plants systemically infected with B11-M than with PVA-M was probably due to the higher multiplication rate of PVA-B11 than PVA-M (Rajamäki et al. 1998), a trait associated with the CP cistron of PVA-B11 (Andrejeva et al. 1999). This difference did not

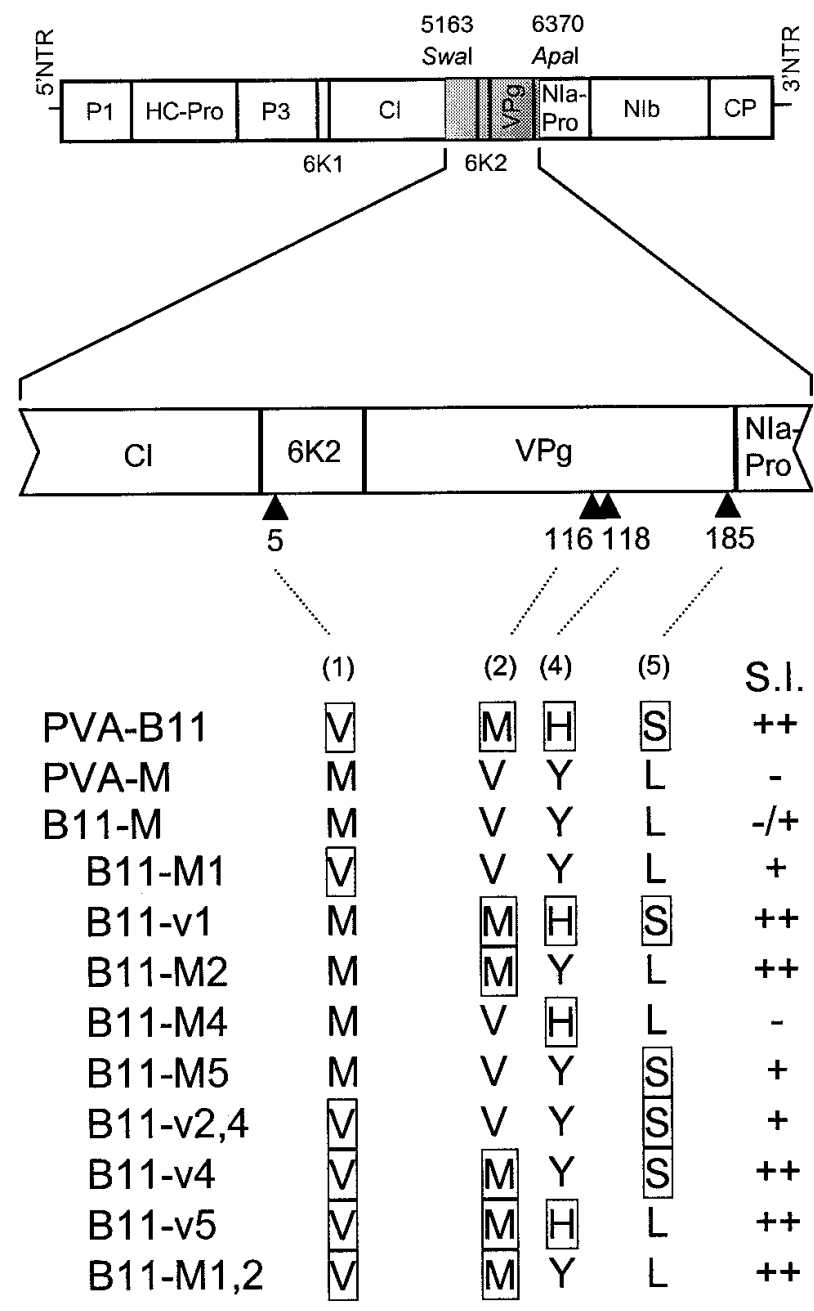

Fig. 1. Schematic map of the recombinant virus B11-M. The genomic region between the unique restriction sites SwaI(5163) and ApaI(6370) in the infectious cDNA clone of PVA-B11 was replaced with the corresponding region cloned from PVA-M. Other mutants were generated by site-directed mutagenesis of PVA-B11 (designated as B11-v...) and B11M (B11-M...). The four amino acid differences between PVA-B11 and PVA-M and their numbers in the $6 \mathrm{~K} 2$ protein and the viral genomelinked protein $(\mathrm{VPg})$ are indicated. In each sequence the amino acid residues different from those of PVA-M (and B11-M) are boxed. Systemic infection (S.I.) in Nicandra physaloides var. Black Pod is indicated to the right: ++ , high amounts of virus $(>1,000 \mathrm{ng} / \mathrm{g})$; + , low amounts of virus $(13-1,000 \mathrm{ng} / \mathrm{g}) ;-$, no virus detected at 14 days after inoculation (see also Table 1). 5'-NTR and $3^{\prime}$-NTR: $5^{\prime}$ and $3^{\prime}$ nontranslated regions, respectively; P1, proteinase; HC-Pro, helper componentproteinase; $\mathrm{P} 3$, the third protein; $6 \mathrm{~K} 1,6 \mathrm{kDa}$ protein 1; CI, helicase; NIa-Pro, proteinase; NIb, replicase; $\mathrm{CP}$, coat protein (Riechmann et al. 1992). affect further studies that were based on comparison of B11-M and PVA-B11. Plants were inoculated at growth stage II by particle bombardment in the subsequent experiments, unless otherwise mentioned.

\section{Single amino acid substitutions in $6 \mathrm{~K} 2$ and $\mathrm{VPg}$ overcome resistance.}

The significance of each of the four amino acid differences between PVA-B11 and B11-M with regard to avirulence was tested by single amino acid substitutions introduced into PVAB11 and B11-M (Fig. 1). The first two recombinants contained a single amino acid substitution in the $6 \mathrm{~K} 2$ protein. B11-M1 (Met5Val in B11-M) and B11-v1 (Val5Met in PVAB11) (Fig. 1) induced systemic infection in 14 and 10 dpi, respectively, whereas systemic infection was not detected in any plant inoculated with B11-M in these experiments. Since the bombarded leaf areas contained similar titers of B11-M (mean $570 \mathrm{ng} / \mathrm{g}$, SE 180) and B11-M1 (580 ng/g, SE 650), both viruses probably moved cell to cell in the mesophyll. Consequently, the detectable difference between the two viruses was that only B11-M1 was able to induce systemic infection. These data indicated that the $6 \mathrm{~K} 2$ protein contributed to the entry into, or movement within, the vascular tissue. Tissue immunoprints provided insufficient resolution to reveal more of the differences in virus movement in the inoculated leaves (data not presented). Hence, the precise cellular interface where the movement of B11-M was blocked and which was overcome by B11-M1 was not determined.

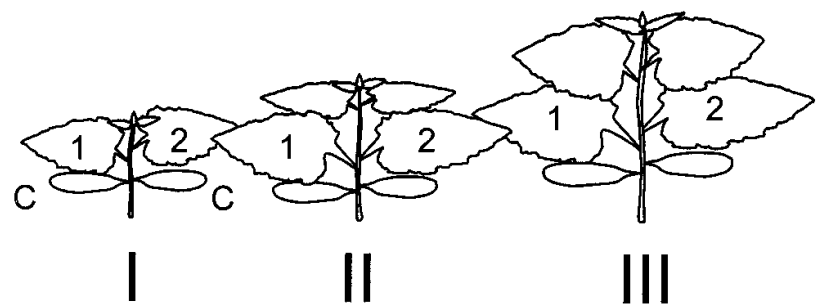

\begin{tabular}{|c|c|c|c|c|c|c|}
\hline & & 1 & & II & & III \\
\hline M & + & $\begin{array}{l}1 / 12 \\
52\end{array}$ & - & $0 / 17$ & - & $0 / 12$ \\
\hline B11-M & + & $\begin{array}{c}15 / 17 \\
330(560)\end{array}$ & + & $\begin{array}{l}1 / 19 \\
19\end{array}$ & - & $0 / 6$ \\
\hline B11 & +++ & $\begin{array}{l}17 / 17 \\
3830(1210)\end{array}$ & +++ & $\begin{array}{l}19 / 19 \\
2280(490)\end{array}$ & +++ & $\begin{array}{l}12 / 12 \\
\mathrm{nt}\end{array}$ \\
\hline
\end{tabular}

Fig. 2. Systemic infection of Nicandra physaloides var. Black Pod with potato virus A (PVA) at three growth stages (I--III) corresponding to the age at 25,30, and 35 days after germination, respectively (growth at $17 / 19^{\circ} \mathrm{C}$ night/day; photoperiod $18 \mathrm{~h}$ ). Plants reached flowering stage at approximately 70 days after germination. Leaves 1 and 2 were inoculated. Virus was detected in the third (expanding) leaf above the inoculated leaves by double antibody sandwich-enzyme-linked immunosorbent assay (DAS-ELISA) at 14 days after inoculation. Numbers of plants infected/total numbers of plants inoculated, and mean amounts of virus (ng/g) estimated by ELISA in the systemically infected leaves, are shown (SE in parentheses). -, no detectable amounts of virus and no symptoms; +, few chlorotic streaks in veins and low amounts of virus; +++ , severe vein chlorosis and high amounts of virus. Inoculated leaves were determined as infected by ELISA. C, cotyledons. 
The leaves systemically infected with B11-M1 developed a few chlorotic streaks on veins and virus titers were low, whereas the leaves infected with B11-v1 developed severe vein chlorosis and contained high virus titers, similar to PVA-B11 (Table 1). Since the substitution Met5Val in B11-M1 did not fully recover the phenotype of PVA-B11 and the substitution Val5Met in PVA-B11 had no phenotypic effect, the amino acid differences in the VPg were also significant for avirulence.

The substitutions Val116Met (B11-M2), Tyr118His (B11M4), and Leu185Ser (B11-M5) were introduced into the VPg of B11-M (Fig. 1). The phenotypic responses to infection with B11-M2 and PVA-B11 were identical (Table 1). Hence, the substitution Val116Met alone could fully overcome resistance. The substitution Leu185Ser could partially overcome resistance since all plants inoculated with B11-M5 were systemically infected but at a slower rate than with B11-M2, similar to B11-M1 (see above). These data confirmed that the VPg, as well as the $6 \mathrm{~K} 2$ protein, were avirulence determinants. The substitution Tyr118His did not overcome resistance since no plants inoculated with B11-M4 were systemically infected at 14 dpi (Table 1).

PVA-B11 containing a double substitution Met116Val and His118Tyr in the VPg (B11-v2,4) induced systemic infection in all inoculated plants, but at a slower rate than PVA-B11 and only low virus titers and a few chlorotic streaks on veins were observed (Table 1). The phenotypic response to B11-v2,4 was therefore consistent with the results obtained with B11-M1 and B11-M5 and showed the same phenotypic effect associated with $\mathrm{Val}^{5}$ and $\mathrm{Ser}^{185}$ in the $6 \mathrm{~K} 2$ protein and the VPg, respectively. These results confirmed that $\mathrm{Met}^{116}$ in the VPg is required to overcome resistance completely. The single amino acid substitution Met116Val was not introduced into PVA-B11, because it would have created an amino acid motif not present in the VPg of any natural PVA isolate analyzed (data not shown).
Additional amino acid substitutions were introduced to the VPg of PVA-B11 (B11-v4 and B11-v5) and a double substitution was introduced to the $6 \mathrm{~K} 2$ protein and the VPg of B11-M $(\mathrm{B} 11-\mathrm{M} 1,2)\left(\right.$ Fig. 1) to have $\mathrm{Met}^{116}$ tested in all contexts of the two other variable amino acid residues in the VPg. Phenotypic responses to all these recombinants were identical to the responses to PVA-B11 and PVA-M2 (Table 1).

Inoculation of $N$. physaloides at the youngest growth stage, stage I, with all recombinant viruses resulted in systemic infection, which showed that all virus mutants were fully capable of vascular movement at the youngest (permissive) growth stage. These data were consistent with the developmental regulation of resistance.

All virus progeny from the systemically infected leaves were checked by cloning the mutated region by RT-PCR and sequencing the product, or by checking the mutated site from the PCR product by restriction analysis with a novel restriction site introduced during site-directed mutagenesis. No sequence reversions in the mutated areas were detected in the virus progeny.

\section{Co-infection with virulent and avirulent isolates.}

The possibility that PVA-M was restricted to the inoculated leaves due to a defense response elicited upon infection was tested rigorously, even though no necrotic symptoms characteristic of a hypersensitive response were observed. The first two true leaves were inoculated with PVA-M (or mockinoculated) at growth stage II. These same leaves, or the third or fourth leaf above them (leaf five or six) were sap inoculated with PVA-B11 4 or 6 days later. All of the total of 26 plants tested in each of these experiments developed vein chlorosis symptoms in the upper leaves $10 \mathrm{dpi}$, high virus titers were detected by ELISA, and RT-PCR analysis confirmed the presence of PVA-B11 only. Infectious cDNA clones of PVA-B11

Table 1. Amounts (ng/g) of potato virus A (PVA) coat protein (CP) antigen in the systemically infected leaves of Nicandra physaloides var. Black Pod inoculated with PVA isolates and mutants at growth stage II $^{\mathrm{a}}$

\begin{tabular}{|c|c|c|c|c|c|}
\hline \multirow[b]{3}{*}{ Virus isolate or construct } & \multirow[b]{3}{*}{ Symptoms 10 dpi $^{\text {b }}$} & \multicolumn{4}{|c|}{ ELISA } \\
\hline & & \multicolumn{2}{|c|}{14 dpi } & \multicolumn{2}{|c|}{18 dpi } \\
\hline & & $\mathbf{N}^{\mathrm{c}}$ & $\mathrm{ng}(\mathrm{SE})^{\mathrm{d}}$ & $\mathbf{N}^{c}$ & ng (SE) \\
\hline B11 & 100 & $19 / 19$ & $2,280(490)$ & $19 / 19$ & $3,130(990)$ \\
\hline M & 0 & $0 / 17$ & 0 & $2 / 17$ & $36(13)$ \\
\hline B11-M & 0 & $1 / 19$ & 19 & $6 / 19$ & $90(99)$ \\
\hline B11-M1 & 0 & $4 / 4$ & $203(180)$ & $4 / 4$ & $1,360(770)$ \\
\hline B11-v1 & 100 & $8 / 8$ & $3,510(730)$ & NT & NT \\
\hline B11-M2 & 100 & $6 / 6$ & $2,630(230)$ & NT & NT \\
\hline B11-M4 & 0 & $0 / 3$ & 0 & $0 / 3$ & 0 \\
\hline B11-M5 & 0 & $2 / 2$ & $360(30)$ & $2 / 2$ & $2,460(69)$ \\
\hline B11-v2,4 & 0 & $7 / 7$ & $390(420)$ & $7 / 7$ & $780(470)$ \\
\hline B11-v4 & 100 & $7 / 7$ & $6,220(1,400)$ & NT & NT \\
\hline B11-v5 & 100 & $4 / 4$ & $1,590(690)$ & NT & NT \\
\hline B11-M1,2 & 100 & $4 / 4$ & $3,610(2,640)$ & NT & NT \\
\hline
\end{tabular}

${ }^{a}$ For explanation, see Figure 2.

${ }^{b}$ Percentage of plants with vein chlorosis symptoms at 10 days post inoculation (dpi). Appearance of symptoms coincided with detectable amounts of PVA (enzyme-linked immunosorbent assay [ELISA] and reverse transcription-polymerase chain reaction [RT-PCR]) in the systemically infected leaves.

${ }^{c}$ Number of plants infected / total number of plants inoculated in at least two experiments, each including PVA-B11 and B11-M as controls. Plants in which inoculated leaves were not infected, as determined by ELISA, are not included.

d Amounts of PVA antigen (ng per g of leaf; SE of mean in parentheses). Comparison to known amounts of purified virions of PVA-B11 (200, 40, 8, 1.6, and $0.32 \mathrm{ng}$ ) was used for setting up the standard curve to estimate amounts of PVA antigen in the samples. Absorbances were read when $200 \mathrm{ng}$ of virions reached the $A_{405}$ value 2.500 ( 30 to $45 \mathrm{~min}$ after adding the substrate). Values for buffer and healthy plants were similar (0.04-0.06) and values twice as high as those of the healthy plants were considered to be virus-positive. Plates were monitored for up to $5 \mathrm{~h}$ after adding the substrate, but the $A_{405}$ values of healthy plants did not increase in any test. The detection threshold of antigen was estimated to be approximately 10 -fold lower than the quantifiable amounts of antigen ( $A_{405}$ values higher than those for $0.32 \mathrm{ng}$ of virions). Numbers are means from two to eight independent experiments. 
and B11-M were co-precipitated on gold particles and bombarded to $N$. physaloides to introduce the two viruses to the same initially infected cells. In addition, PVA-M and PVAB11 were sap inoculated to the same leaves in a mixed inoculum. Eight and 12 plants, respectively, were inoculated in these experiments and all were systemically infected only with PVA-B11, as detected by RT-PCR, at 10, 14, and $18 \mathrm{dpi}$. These experiments did not provide evidence for induced resistance. On the other hand, they also showed that PVA-B11 could not complement the systemic infection with PVA-M and B11-M in N. physaloides.

\section{DISCUSSION}

Results of this study indicate that the $6 \mathrm{~K} 2$ protein and the VPg are avirulence determinants of isolate PVA-M in Nicandra physaloides var. Black Pod resistant to this PVA isolate. Specific amino acid substitutions in the 6K2 protein (amino acid 5) and the VPg (amino acids 116 and 185) of PVA-M permitted the virus to overcome the resistance. The $6 \mathrm{~K} 2$ protein has not been reported previously as an avirulence determinant or been reported to be involved in virus movement. Both roles have been assigned to the VPg in TVMV and TEV in previous studies (Nicolas et al. 1997; Schaad et al. 1997b). The VPg of PSbMV is also an avirulence factor in pea plants that carry the gene $s b m-1$ reported to confer resistance to infection (Keller et al. 1998).

Substitution Met5Val introduced to the $6 \mathrm{~K} 2$ protein in B11$M$ permitted vascular transport and systemic infection without altering virus accumulation in the inoculated leaves, which indicates a crucial role for $\mathrm{Val}^{5}$ in the $6 \mathrm{~K} 2$ protein for virus movement. Previous studies have shown that the $6 \mathrm{~K} 2$ protein is involved in virus replication (Restrepo-Hartwig and Carrington 1994; Schaad et al. 1997a), but the data from this study indicate that it has multiple functions in both virus replication and movement. The model for the function of the $6 \mathrm{~K} 2$ protein in virus replication includes that the $6 \mathrm{~K} 2$ protein is bound to the endoplasmic reticulum (ER) (Restrepo-Hartwig and Carrington 1994) and anchors the replication complex to the site of replication (Schaad et al. 1996, 1997a). This is supported by the data showing that the $6 \mathrm{~K} 2$ protein may exist as a polyprotein with the CI protein, the VPg (processed from the $\mathrm{N}$-terminal domain of the NIa protein and covalently bound to the 5' end of viral RNA; Murphy et al. 1991), or the unprocessed NIa protein that are putative components of the replication complex (Restrepo-Hartwig and Carrington 1994; Schaad et al. 1996, 1997a). Proteolytic processing of the polyproteins by NIa-Pro (the C-terminal domain of the NIa protein) is necessary for infectivity (Schaad et al. 1996, 1997a) and the protein-RNA complex may be released from the ER by cleavage at the 6K2/VPg proteolytic site (Schaad et al. 1996, 1997a). The position of the N-terminal $\mathrm{Val}^{5}$ found to be important for virus movement in this study is different from the hydrophobic domain of the $6 \mathrm{~K} 2$ protein believed to be involved in membrane binding (amino acids 22 to 44 in the $6 \mathrm{~K} 2$ protein of TEV; Schaad et al. 1997a). Since the N terminus of the 6K2 protein probably resides on the cytoplasmic side of the membrane (Schaad et al. 1997a), it may interact with other viral and/or host proteins and substitutions therein may affect the conformation of putative protein complexes, e.g., those possibly required for virus movement.
The role of the $6 \mathrm{~K} 2$ protein in virus movement may be similar to the function of the $30 \mathrm{~K}$ movement protein of tobacco mosaic virus (genus Tobamovirus). The $30 \mathrm{~K}$ protein is bound to the cortical ER and proposed to mediate intracellular translocation of the viral RNA-protein complex along microtubules to the openings of plasmodesmata for cell-to-cell translocation (Heinlein et al. 1998; Reichel and Beachy 1998). Furthermore, the $30 \mathrm{~K}$ protein is able to increase the size exclusion limit of plasmodesmata (Wolf et al. 1989). The ERbound $6 \mathrm{~K} 2$ protein may have similar roles in translocating PVA, perhaps in the form of an RNA-protein complex resembling the above-described complex putatively involved in virus replication (Restrepo-Hartwig and Carrington 1994; Schaad et al. 1996, 1997a), within and between cells. Indeed, previous authors have indicated that both poty- and tobamovirus probably move from cell to cell as viral RNA-protein complexes (Dorokhov et al. 1984; Dolja et al. 1994; Karpova et al. 1997; Rodríguez-Cerezo et al. 1997; Carrington et al. 1998; Ding 1998).

The similar phenotypic effect of the $\mathrm{N}$-terminal amino acid substitution in the $6 \mathrm{~K} 2$ protein and the $\mathrm{C}$-terminal amino acid substitution (amino acid 185) in the VPg may be a coincidence, or, alternatively, it suggests a coordinated role for the two proteins in virus movement. Since the two proteins can occur as a polyprotein and be components of the same proposed protein complex (Schaad et al. 1996, 1997a), coordinated functions are conceivable. However, the amino acid substitution in the central part of VPg (amino acid 116) had a profound impact on systemic infection and virus accumulation in the systemically infected leaves, which does not exclude the possibility that both virus movement and replication were affected. In previous studies, amino acid substitutions at the corresponding central part (Nicolas et al. 1997) and at a more N-proximal part of the VPg (Schaad et al. 1997b) allowed TVMV and TEV, respectively, to overcome resistance to virus movement in the mesophyll and vascular tissue, respectively. The different phenotypes caused by mutations in the same region of the VPg in different viruses and hosts are difficult to explain, unless the possibility is considered that the functions of the VPg in virus-host interactions are at least partially mediated indirectly through protein complexes. Consequently, the possible additional amino acid differences in the other viral proteins involved in the complex (e.g., the $6 \mathrm{~K} 2$ protein) may influence the ultimate phenotypic outcome. In our study, the impact of the amino acid substitution at the central region of the VPg (amino acid 116) was so predominant that it masked the phenotypic effect of the substitution in the $6 \mathrm{~K} 2$ amino acid 5 (and at the VPg amino acid 185). The cellular and subcellular effects of each of the three significant amino acid substitutions will be a subject for further study.

Resistance to systemic infection with PVA-M in N. physaloides developed during plant growth. The youngest plants were systemically infected with B11-M, and after establishing systemic infection the virus continued to infect the young leaves at the top of the plant. In contrast, few or no plants inoculated at an older growth stage were systemically infected. However, PVA-B11 and many virus mutants induced systemic infection independent of the growth stage. Therefore, lack of systemic movement of B11-M was not associated with changes in the sink-source relationships between leaves, which affects virus transport in plants in a universal manner 
(Leisner et al. 1993; Santa Cruz 1999). Rather, these results may be explained by changes in gene expression during maturation of phloem tissue (Sjölund 1997) and an altered availability of putative host factors interacting with the viral MPs (Leisner et al. 1993; Oparka et al. 1999). This is consistent with the recent studies showing that the transport of macromolecules is more strictly controlled in the mature than the immature phloem and the control is different in source and sink tissues (Imlau et al. 1999; Oparka et al. 1999; Santa Cruz 1999). Assuming simply a dose effect, while a high dose of factors showing less compatible interactions might mediate virus transport to the same rate as a lower dose of factors that match completely, a declining dose of the required host factor(s) during phloem maturation would affect the less compatible virus isolate much more drastically than a compatible isolate. For instance, reduced affinity of mouse hepatitis virus (MHV) to a naturally divergent biliary glycoprotein 1 isoform in an inbred mouse strain makes these mice highly resistant to MHV. Reduction of affinity by 10 - to 100 -fold is sufficient to reduce MHV titers in the major target organs by $10^{9}$-fold (Ohtsuka et al. 1996).

Responsiveness of plants to pathogen infection is dependent on development, since young seedlings are unable to respond (Honée et al. 1998; Weber and Pfitzner 1998). Therefore, an induced resistance response was considered as a possible mechanism of resistance to PVA in $N$. physaloides. For instance, a genomic region spanning the $6 \mathrm{~K} 2$ domain is involved in a wilting response induced by TEV in Tabasco pepper (Chu et al. 1997) and some viral MPs induce a virusspecific or virus strain-specific hypersensitive resistance response in plants (Weber and Pfitzner 1998; Malcuit et al. 1999). However, the data did not provide evidence for induced resistance resembling the hypersensitive response or systemic acquired resistance in $N$. physaloides, which was consistent with previous studies that have described the VPg as an avirulence determinant (Nicolas et al. 1997, Schaad et al. 1997b; Keller et al. 1998). The result that PVA-B11 could not complement systemic infection of PVA-M and B11-M in coinoculated leaves and cells, respectively, of $N$. physaloides was expected since a previous study had indicated that the $6 \mathrm{~K} 2$ protein and the VPg mediate their functions in cis (Schaad et al. 1996).

\section{MATERIALS AND METHODS}

\section{Virus isolates and plants.}

The PVA isolates B11 and M have been previously described (Valkonen et al. 1995; Rajamäki et al. 1998). The complete nucleotide and amino acid sequences of PVA-B11 have been published and a full-length infectious cDNA clone is available (Puurand et al. 1996; Andrejeva et al. 1999). Sequences for HC-Pro and CP from PVA-M have been published (Rajamäki et al. 1998). The sequence for the genomic region between the nucleotides 5163 and 6370 encoding the 6K2 protein and the VPg was determined from PVA-M in this study (EMBL accession no. AJ132007).

Seeds of $N$. physaloides var. Black Pod were obtained from B\&T World Seeds (Olonzac, France). Plants were grown under constant conditions in a growth chamber $\left(8.8 \mathrm{~m}^{2}\right.$; Weiss Umweltstechnik, Germany). The photoperiod was $18 \mathrm{~h}$ (250 $\mu \mathrm{mol} \mathrm{s}{ }^{-1} \mathrm{~m}^{-2}$ ), the temperature was $19 / 17^{\circ} \mathrm{C}$ (day/night), and the relative humidity was $40 \%$. Plants were watered daily and fertilized weekly with $0.5 \%$ N:P:K = 5:7:6 fertilizer (Kukkien Ylannos, Kemira OY, Finland).

\section{Cloning and mutagenesis.}

Total RNA was purified from virus-infected leaves with the RNeasy Plant Mini system (Qiagen, Hilden, Germany). Firststrand cDNA synthesis was carried out with Moloney murine leukemia virus (M-MLV) reverse transcriptase (Promega, Madison, WI) primed with random hexamers $\left[(\mathrm{dN})_{6}\right.$; Promega]. Viral sequences were amplified by PCR. Cloning was done by standard procedures (Sambrook et al. 1989).

Sequencing was done on both strands from at least two independent PCR-amplified clones with the ThermoSequenace kit (Amersham, Cleveland, $\mathrm{OH}$ ). The sequencing reactions were analyzed on an automated Perkin Elmer ABI 377XL DNA sequencer (Norwalk, CT) or an A.L.F. Express DNA sequencer (Pharmacia Biotechnology, Uppsala, Sweden). Sequences were numbered according to PVA-B11 (Puurand et al. 1994).

Recombinant viruses were constructed to the vector containing the full-length infectious cDNA of PVA-B11 (Puurand et al. 1996) placed under the cauliflower mosaic virus $35 \mathrm{~S}$ promoter. To obtain the recombinant virus B11-M, a 1,208nucleotide fragment (nucleotides 5163 to 6370) was amplified from PVA-M cDNA by PCR, cloned into the vector pGEM-T (Promega), sequenced, and transferred to the cDNA of PVAB11 with the unique $S w a \mathrm{I}$ and ApaI restriction sites (Fig. 1). Point mutations were generated with the QuikChange SiteDirected Mutagenesis system (Stratagene, La Jolla, CA) and the appropriate DNA oligonucleotide primers. For sitedirected mutagenesis of PVA-B11 cDNA, a 1,898-nucleotide fragment was generated by HindIII-ApaI digestion and subcloned into the pBluescript vector (Stratagene), whereas for B11-M the cloned SwaI-ApaI fragment was used (Table 1). Mutations were verified by sequencing and the mutated clones transferred to PVA-B11 cDNA with the SwaI and ApaI sites.

\section{Virus inoculation and detection.}

The PVA cDNA constructs were inoculated to N. physaloides var. Black Pod with the Helios Gene Gun System (BioRad Laboratories, Hercules, CA). Gold particles (diameter 1.0 or $1.6 \mu \mathrm{m}$; BioRad Laboratories) were coated with plasmid DNA linearized by $\mathrm{AgeI}$ (Promega) followed by precipitation with 99.5\% ethanol. Cartridges were prepared according to the Helios Gene Gun System Instruction Manual (BioRad). In coinoculation experiments, gold particles were simultaneously coated with cDNA of two constructs. The first full-grown leaves (leaves 1 and 2; Fig. 2) were inoculated by one or two shots each at $200 \mathrm{lb} / \mathrm{in}^{2}$.

Young leaves were harvested at the same time from plants of Nicotiana tabacum L. 'Samsun' systemically infected with PVA-M, PVA-B11, or B11-M. Samples were taken from them for the determination of the virus amounts by ELISA, and the leaves were frozen. The same batch of frozen leaves was used for all inoculations. Virus amounts in inocula were adjusted to a similar level for all isolates and mutants (corresponding to 200 ng of PVA CP antigen per $\mathrm{ml}$ ) by diluting the sap with sterile, distilled water.

PVA was detected by double antibody sandwich (DAS)ELISA with a monoclonal antibody (MAb) and an alkaline 
phosphatase-conjugated MAb to PVA (MAb 58/0; Adgen, UK) as previously described (Rajamäki et al. 1998). The entire inoculated leaves were sampled, whereas, from the leaves inoculated by particle bombardment, the bombarded area was excised with a cork borer (diameter $2 \mathrm{~cm}$ ). The samples were weighed, then ground in ELISA extraction buffer at $1 \mathrm{~g}$ per $3 \mathrm{ml}$, and two aliquots of $100 \mu \mathrm{l}$ were transferred to the ELISA microtiter plate (Greiner Labortechnik, Frickenhausen, Germany). Known amounts of purified virions of PVA-B11 (0.32, 1.6, 8, 40, and $200 \mathrm{ng})$ were included for setting up the standard curve used to estimate the virus amounts in leaves. Systemic infection was detected from the fourth (14 dpi) or fifth (18 dpi) leaf above the inoculated leaves (see Table 1 for further details). The sampled, noninoculated leaves were still expanding at the sampling time and presented sinks for photoassimilates.

\section{ACKNOWLEDGMENTS}

We thank Tuija Kekarainen and Andres Merits for fruitful discussions during the study, and Eugene Savenkov for critically reading the manuscript. Financial support from the Academy of Finland (grant nos. 34529 and 36256), SJFR (grant no. 32.0667/97), and EC (BIO4-CT97-2356) is gratefully acknowledged.

\section{LITERATURE CITED}

Andrejeva, J., Puurand, Ü., Merits, A., Rabenstein, A., Järvekülg, L., and Valkonen, J. P. T. 1999. Potyvirus HC-Pro and CP proteins have coordinated functions in virus-host interactions and the same $\mathrm{CP}$ motif affects virus transmission and accumulation. J. Gen. Virol. 80: 1133-1139.

Bartels, R. 1971. Potato virus A. No. 54 in: Descriptions of Plant Viruses. Commonw. Mycol. Inst./Assoc. Appl. Biol., Kew, U.K.

Carrington, J. C., Jensen, P. E., and Schaad, M. C. 1998. Genetic evidence for an essential role for potyvirus CI protein in cell-to-cell movement. Plant J. 14:393-400.

Chu, M., Lopez-Moya, J. J., Llave-Correas, C., and Pirone, T. P. 1997. Two separate regions in the genome of the tobacco etch virus contain determinants of the wilting response of Tabasco pepper. Mol. PlantMicrobe Interact. 10:472-480.

Cronin, S., Verchot, J., Haldeman-Cahill, R., Schaad, M. C., and Carrington, J. C. 1995. Long-distance movement factor: A transport function of the potyvirus helper component-proteinase. Plant Cell 7: 549-559.

Culver, J. N. 1997. Viral avirulence genes. Pages 196-219 in: PlantMicrobe Interactions. Vol. 2. G. Stacey and N. T. Keen, eds. Chapman and Hall, New York.

De Wit, P. J. G. M. 1997. Pathogen avirulence and plant resistance: A key role for recognition. Trends Plant Sci. 2:452-458.

Ding, B. 1998. Intercellular protein trafficking through plasmodesmata. Plant Mol. Biol. 38:279-310.

Dolja, V. V., Haldeman, R., Robertson, N. L., Dougherty, W. G., and Carrington, J. C. 1994. Distinct functions of capsid protein in assembly and movement of tobacco etch potyvirus in plants. EMBO J. 13: 1482-1491.

Dorokhov, Y. L., Alexandrova, N. M., Miroshnichenko, N. A., and Atabekov, J. G. 1984. The informosome-like virus-specific ribonucleoprotein (vRNP) may be involved in the transport of tobacco mosaic virus infection. Virology 137:127-134.

Faquet, M. C., and Mayo, M. A. 1999. Abbreviations for plant virus names - 1999. Arch. Virol. 144:1249-1273.

Fellers, J., Wan, J., Hong, Y., Collins, G. B., and Hunt, A. G. 1998. In vitro interactions between a potyvirus-encoded, genome-linked protein and RNA-dependent RNA polymerase. J. Gen. Virol. 79:20432049.

Heinlein, M., Padgett, H. S., Gens, J. S., Pickard, B. G., Casper, S. J., Epel, B. L., and Beachy, R. N. 1998. Changing patterns of localization of the tobacco mosaic virus movement protein and replicase to the endoplasmic reticulum and microtubules during infection. Plant Cell 10:1107-1120.

Honée, G., Buitink, J., Jabs, T., De Kloe, J., Sijbolts, F., Apotheker, M., Weide, R., Sijen, T., Stuiver, M., and De Wit, P. J. G. M. 1998. Induction of defense-related responses in Cf9 tomato cells by the AVR9 elicitor peptide of Cladosporium fulvum is developmentally regulated. Plant Physiol. 117:809-820.

Imlau, A., Truernit, E., and Sauer, N. 1999. Cell-to-cell and longdistance trafficking of the green fluorescent protein in the phloem and symplastic unloading of the protein into sink tissues. Plant Cell 11: 309-322.

Karpova, O. V., Ivanov, K. I., Rodionova, N. P., Dorokhov, Y., and Atabekov, J. G. 1997. Nontranslatability and dissimilar behaviour in plants and protoplasts of viral RNA and movement protein complexes formed in vitro. Virology 230:11-21.

Kekarainen, T., Merits, A., Oruetxebarria, I., Rajamäki, M.-L., and Valkonen, J. P. T. 1999. Comparison of the complete sequences of five different isolates of Potato virus A (PVA), genus Potyvirus. Arch. Virol.144:1-12.

Keller, K. E., Johansen, I. E., Martin, R. R., and Hampton, R. O. 1998. Potyvirus genome-linked protein $(\mathrm{VPg})$ determines pea seed-borne mosaic virus pathotype-specific virulence in Pisum sativum. Mol. Plant-Microbe Interact. 11:124-130.

Lai, M. M. C. 1998. Cellular factors in the transcription and replication of viral RNA genomes: A parallel to DNA-dependent RNA transcription. Virology 244:1-12.

Leisner, S. M., Turgeon, R., and Howell, S. H. 1993. Effects of host plant development and genetic determinants on the long distance movement of cauliflower mosaic virus in Arabidopsis. Plant Cell 5: 191-202.

Malcuit, I., Marano, M. R., Kavanagh, T. A., De Jong, W., Forsyth, A., and Baulcombe, D. 1999. The 25-kDa movement protein of PVX elicits $N b$-mediated hypersensitive cell death in potato. Mol. PlantMicrobe Interact. 12:536-543.

Masuta, C., Nishimura, M., Morishita, H., and Hataya, T. 1999. A single amino acid change in viral genome-associated protein of potato virus Y correlates with resistance breaking in 'Virgin A mutant' tobacco. Phytopathology 89:118-123.

Murphy, J. F., Rychlik, W., Rhoads, R. E., Hunt, A. G., and Shaw, J. G. 1991. A tyrosine residue in the small nuclear inclusion protein of tobacco vein mottling virus links the VPg to the viral RNA. J. Virol. 65: 511-513.

Nicolas, O., Dunnington, S. W., Gotow, L. F., Pirone, T. P., and Hellmann, G. M. 1997. Variations in the VPg protein allow a potyvirus to overcome va gene resistance in tobacco. Virology 237:452-459.

Ohtsuka, N., Yamada, Y. K., and Taguchi, F. 1996. Difference in virusbinding activity of two distinct receptor proteins for mouse hepatitis virus. J. Gen. Virol. 77:1683-1692.

Oparka, K. J., Roberts, A. G., Boevink, P., Santa Cruz, S., Roberts, I., Pradel, K. S., Imlau, A., Kotlizky, G., Sauer, N., and Epel, B. 1999. Simple, but not branched, plasmodesmata allow the nonspecific trafficking of proteins in developing tobacco leaves. Cell 97:743754.

Puurand, Ü., Mäkinen, K., Paulin, L., and Saarma, M. 1994. The nucleotide sequence of potato virus A genomic RNA and its sequence similarities with other potyviruses. J. Gen. Virol. 75:457-461.

Puurand, Ü., Valkonen, J. P. T., Mäkinen, K., Rabenstein, F., and Saarma, M. 1996. Infectious in vitro transcripts from cloned cDNA of the potato A potyvirus. Virus Res. 40:135-140.

Rajamäki, M., Merits, A., Rabenstein, F., Andrejeva, J., Paulin, L., Kekarainen, T., Kreuze, J. F., Forster, R. L. S., and Valkonen, J. P. T. 1998. Biological, serological, and molecular differences among isolates of potato A potyvirus. Phytopathology 88:311-321.

Reichel, C., and Beachy, R. N. 1998. Tobacco mosaic virus infection induces severe morphological changes of the endoplasmic reticulum. Proc. Natl. Acad. Sci. USA 95:11169-11174.

Restrepo-Hartwig, M. A., and Carrington, J.C. 1994. The tobacco etch potyvirus 6-kilodalton protein is membrane associated and involved in viral replication. J. Virol. 68:2388-2397.

Riechmann, J. L., Laín, S., and Garcia, J. A. 1992. Highlights and prospects of potyvirus molecular biology. J. Gen. Virol. 73:1-16.

Rodríguez-Cerezo, E., Findlay, K., Shaw, J. G., Lomonossoff, G. P., Qiu, S. G., Linstead, P., Shanks, M., and Risco, C. 1997. The coat and cylindrical inclusion proteins of a potyvirus are associated with connec- 
tions between plant cells. Virology 236:296-306.

Sambrook, J., Fritsch, E. F. and Maniatis, T. A. 1989. Molecular Cloning: A Laboratory Manual. 2nd ed. Cold Spring Harbor Laboratory, New York.

Santa Cruz, S. 1999. Perspective: Phloem transport of viruses and macromolecules - what goes in must come out. Trends Microbiol. 7:237241.

Schaad, M. C., Haldeman-Cahill, R., Cronin, S., and Carrington, J. C. 1996. Analysis of the VPg-proteinase (NIa) encoded by tobacco etch potyvirus: Effects of mutations on subcellular transport, proteolytic processing, and genome amplification. J. Virol. 70:7039-7048.

Schaad, M. C., Jensen, P. E., and Carrington, J. C. 1997a. Formation of plant RNA virus replication complexes on membranes: Role of an endoplasmic reticulum-targeted viral protein. EMBO J. 16:4049-4059.

Schaad, M. C., Lellis, A. D., and Carrington, J. C. 1997b. VPg of tobacco etch potyvirus is a host genotype-specific determinant for longdistance movement. J. Virol. 71:8624-8631.

Shahabuddin, M., Shaw, J. G., and Rhoads, R. E. 1988. Mapping of the tobacco vein mottling virus VPg cistron. Virology 163:635-637.

Shaner, G., Stromberg, E. L., Lacy, G. H., Barker, K. R., and Pirone, T.
P. 1992. Nomenclature and concepts of pathogenicity and virulence. Annu. Rev. Phytopathol. 30:47-66.

Shukla, D. D., Ward, C. W., and Brunt, A. A. 1994. The Potyviridae. CAB Int., Wallingford, UK. p. 516.

Sjölund, R. D. 1997. The phloem sieve element: A river runs through it. Plant Cell 9:1137-1146.

Valkonen, J. P. T., Puurand, Ü., Slack, S. A., Mäkinen, K., and Saarma, M. 1995. Three strain groups of potato A potyvirus based on hypersensitive responses in potato, serological properties, and coat protein sequences. Plant Dis. 79:748-753.

Wang, H.-L., Wang, Y., Giesman-Cookmayer, D., Lommel, S. A., and Lucas, W. J. 1998. Mutations in viral movement protein alter systemic infection and identify an intercellular barrier to entry into the phloem long-distance transport system. Virology 245:75-89.

Weber, H., and Pfitzner, A. J. P. 1998. Tm- $2^{2}$ resistance in tomato requires recognition of the carboxy terminus of the movement protein of tomato mosaic virus. Mol. Plant-Microbe Interact. 11:498-503.

Wolf, S., Deom, C. M., Beachy, R. N., and Lucas, W. J. 1989. Movement protein of tobacco mosaic virus modifies plasmodesmatal size exclusion limit. Science 246:377-379. 